\title{
Understanding the Interaction of Innovation System Dimensions and Organizational Culture: A Review on Technology Firms
}

\section{Kağan Okatan ${ }^{1}$}

\begin{abstract}
Today, organizations see innovation as the main factor in gaining and sustaining competitive advantage. In addition, another important issue is to make innovation sustainable. The literature on innovation includes a lot of research, and every research opens up new research area. In order to ensure sustainable innovation, it is necessary to integrate an appropriate innovation system and culture into the organization. This study focuses on these two factors in particular. The interaction between the dimensions of the innovation system and the culture of the organization is explained by examining sample companies from both developed and developing countries. Exemplary companies were chosen from technology companies, where innovation is at the forefront. The innovation systems of the companies were measured on the basis of their dimensions and the types of corporate cultures were measured in the same way and meaningful relationships were explained by applying the multivariate regression model.
\end{abstract}

Keywords: Innovation Management, Innovation System, Innovation Dimensions, Knowledge Management, Organization

\footnotetext{
${ }^{1}$ Dr. Istanbul Aydin University, Department of Business Management, kaganokatan@aydin.edu.tr, Orcid: 0000-0002-0517-665X

*Received: 15.01.2021, Accepted: 26.02.2021.

DOI: 10.17932/IAU.FCPE.2015.010/fcpe_v07i1001
} 
Understanding the Interaction of Innovation System Dimensions and Organizational Culture: A Review on Technology Firms

\section{INTRODUCTION}

Innovation is an 'indispensable' strategy for every company that seeks to earn considerable revenue and to achieve a large share in the market or to maintain its current market share. In other words, innovation is defined as one of the basic competencies that companies need to develop, maintain and even remain in an environment including rapid change and intense competition (Zhang, Chen, Wang, \& Ordóñez de Pablos, 2016). As a result of these facts, innovation is at the top of corporate strategies. Being an innovative company requires, continuously developing unique products and services.

There are several challenging factors to be innovative and stay innovative. First, it is necessary to establish and maintain an organizational culture in which the innovation within the organization will begin, support and adopt continuous innovation. This is not easy (Phillips, 2007). Institutions with high performance, share many common organizational cultural characteristics, but the pattern of injury from each organization may vary. Organizational culture is a key element in the realization of the mission and strategies of an institution, in increasing institutional effectiveness and in managing change. Many authors and researchers have defined the organizational culture phenomenon in many ways. Organizational culture is often seen as a set of beliefs, values and assumptions shared by the members of the organization (Chang, Liao, \& Wu, 2017). Organizational culture, with its undeniable influence on group motivation and organizational behavior is a very powerful factor on institutional innovation. Strong cultures can both prevent or support changes or new strategies when needed most. The direction of this effect depends on the dimensions of the culture. In this study, the main reason for taking the degree of organizational culture types as an independent variable is determining the level of positive effect according to culture types. 
Figure 1: Research Model (Hypotheses Development)

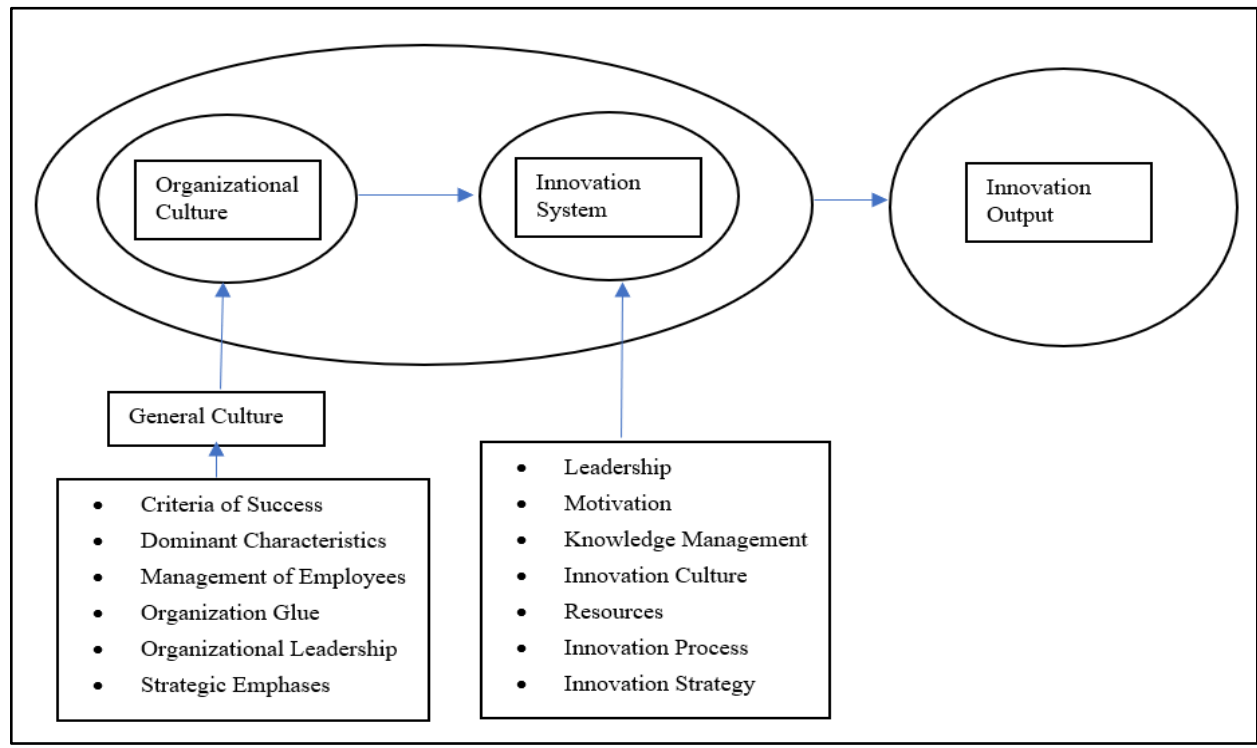

Figure 1 above shows the constructed research model and the hypotheses development

of this study. The following hypotheses were produced based on the research questions:

$H_{1}$ : At least one type of organizational culture is associated with the innovation dimensions of firms.

The adhocracy organizational culture highlights future orientation, risktaking, flexibility, openness, change rewards and organizational learning. These cultural features support firms to adapt to the new environment and to gather critical resources for innovative and creative initiatives (Tian, Deng, Zhang, \& Salmador, 2018).

$H_{2}$ : At least one type of externally oriented organizational culture has a positive relationship with the innovation dimensions of companies.

The company's ability to innovate is the most important factor for competitive advantage under multivariate market conditions. Innovation capability enables the organization to innovate to respond to a changing market environment and continuously incorporate it into all strategies, 
Understanding the Interaction of Innovation System Dimensions and Organizational Culture: A Review on Technology Firms

systems and structures that support innovation in an organization (Rajapathirana \& Hui, 2018).

$H_{3}$ : At least one type of organizational culture with organic processes has a positive relationship with the innovation dimensions of companies.

This innovation capability consists of multiple dimensions which feed innovation output in a way. Institutions can control the dimensions which are internal. Major internal innovation dimensions which are considered in this study are Motivation, Culture, Knowledge Management, Leadership, Process, Resources and Strategy of the institutions. The high-level existence of these dimensions effects the innovativeness positively. This is the reason of the selection of these dimensions as dependent variables in this study.

The interaction between the dimensions of innovation and the cultural dimensions of organizations should be explored for providing an effective innovation implementation method for leaders. The aim of this study is to test the relationships between the innovation system dimensions and the organizational culture types of technology companies which are thought to be innovative. The specific business area for this study is set as 'information technologies' because of the importance of the innovative outputs in this business area. This business area is very sensitive to information and knowledge production which also requires innovative skills. So, it is very important to identify the organizational culture type which fosters innovative behavior and innovative outputs for technology business. We approach organizational culture from competing values framework perspective in this study. We aim to measure the organizational culture based on 'organizational focus' and 'organizational preference for structure'. This study covers 14 Information technology companies which work on software development, system integration and information and communication technologies consulting. The reason behind the selection of these companies is that companies have been in innovative company rankings for a while. Especially developed country examples are companies that have taken place in these rankings. The examples taken from developing countries, on the other hand, are showing a high 
acceleration in their growth and being among the most innovative companies in their own countries. More detailed information about these companies can be found in 'data scope' section. The selection of the information technology business area as the scope of this study is strongly based on the fact that the innovation capability plays crucial role on competitive advantage especially in knowledge-intensive industries. The companies are selected from both 'developed' and 'developing' countries to have a wide point of view.

\section{LITERATURE REVIEW}

It is generally accepted that organizational culture has a significant impact on the tendency of an organization to innovate. Organizational culture is considered to be the primary determinant of innovation, which is integral in nature and which is inseparable from the culture that facilitates or limits the 'value added' capability. It is emphasized that organizational culture affects the level of encouragement, support and implementation of creative solutions. Organizational culture is considered as one of the key elements in increasing and preventing innovation. Different kinds of innovations are thought to require different kinds of organizational culture. Within the scope of studies on the research of organizational culture types, we see that most of them are related to innovation (Chang, Liao, \& Wu, 2017).

Okatan and Alankuş (2017) investigated the 'effect of organizational culture on internal innovation capacity' on the various innovative companies form various industries. They highlighted the influence of the competition culture on reaching the innovative outputs.

Yeşil and Kaya (2013) investigated the effect of organizational culture on firms' financial performance through competing values framework. Although they were not able to demonstrate a direct link between cultural dimensions and financial performance of the companies, their study supported the theoretical argument that organizational culture influenced the performance outcomes by the mediators such as knowledge transformation, knowledge management and innovation. The result of the study also supports empirical studies showing the indirect impact of organizational culture on performance. 
The literature is generally followed by Burns and Stalker typology, which shows a segregation between mechanical and organic organizations. Both expressions describe both mechanical and organic, organizational builds and organizational cultures. We can speak of a lateral communication in organic cultures. In other words, employees in the research and development department directly speak to their colleagues in the marketing or any other department. Organic organizations are considered adaptable and flexible, which makes them more sensitive to the market. Organic cultures tend to provide a collaborative environment that can foster risk taking, increase employee aspirations, and / or help a business grow and increase its chances of success (Wei, Samiee, \& Lee, 2014). There is quite vertical communication with the boss or any other department in mechanical cultures. Decision making in organic cultures is usually guided or influenced by employees who do not rely on a hierarchical position and who are technologically and / or market conscious. In addition, workers in organic cultures have more opportunities to be open to new ideas, technologies, or market views than can be accepted in mechanical cultures. Therewithal, organic cultures encourage the idea and knowledge exchange, instead of highlighting a oneway flow from a central authority. The existence of this mutual knowledge and exchange of ideas provides a more flexible structure for information processing in organic cultures, and therefore it is more likely to determine the potential for innovation.

\section{Competing Values Framework}

Another dimension has also been used for the measurement of organizational culture. It is introduced by Quinn and colleagues as well as Cameron and Freeman. This dimension segregates between the focus on internal orientation and integration, and the emphasis on external orientation and differentiation. Finally, four culture types which are 'clan', 'hierarchy', 'adhocracy' and 'market' derive from this approach and form the competing values framework (Herzog, 2011).

\section{The Hierarchy Culture}

In this culture, a government can be mentioned in the framework of formal rules and procedures. The purpose of the organization is a stable productivity and wants to predict the long-term. The dominant leaders in this culture aim to ensure that the institution operates in a smooth and problem-free climate. Large institutions, especially government agencies, 
work with this type of culture with the effect of the size of the number of employees. It should be noted that this culture is not observed only in very large institutions. Smaller institutions with smaller but very standard and low creativity also adopt this kind of culture because the main purpose in such institutions is efficiency, speed and standardization (Cameron \& Quinn, 2005).

\section{The Market Culture}

Another type of culture is still preferred in the late 1960s with the challenges of competition. It contains very different assumptions according to the hierarchy. This type of culture is called 'Market'. The marketplace is not same with marketing functions or consumers in the market; It is not directed to the inside but is oriented towards the outside. The focus is to create a 'competitive advantage'. Profitability, resultorientation, power in the market areas, forcing targets and customer bases are the main targets. The fundamental values that prevail are competitiveness and efficiency. The leaders of this culture are challenging and demanding. It is important to go beyond competition and market leadership (Cameron \& Quinn, 2005).

\section{The Clan Culture}

'Clan' culture is another form of organization. This type of organization is named as 'clan' because it resembles a family type organization. The common values and objectives have enabled co-operation and cohesion in the firms with clan type. It recalls a large family of economic assets. Typical features are teamwork, employee loyalty programs and corporate commitment to employees rather than hierarchical rules and procedures or competitive profit centers of markets. It strengthens such cultural workers and defines their participation, commitment and loyalty. Some basic assumptions are that the environment is managed through the best teamwork and employee development, the customer is the best partner and is in the organization.

This culture provides an intimate atmosphere with lots of sharing. Leaders are considered mentors, perhaps even parental figures. The organization emphasizes the long-term benefits of individual development with high commitment and moral importance. Work, participation and consensus are important values. (Cameron \& Quinn, 2005). 
Understanding the Interaction of Innovation System Dimensions and Organizational Culture: A Review on Technology Firms

\section{The Adhocracy Culture}

The emergence of this type of organization has been with the transition to the contemporary information age. Besides its half-life product and service advantages, it is based on different assumptions from other organizational structures. These assumptions are that organizations are primarily aimed at developing new products and services and preparing them for the future, and that the greatest task of management is to strengthen entrepreneurship, creativity and the environment.

The origin of the word adhocracy is temporary. It implies something temporary, special and dynamic. This type of culture is generally seen in sectors such as aviation, software development and film production. A major challenge for these organizations is to produce innovative products and services and to quickly adapt to new opportunities. Different from markets or hierarchies, there is no centralized power or authority relationship. Instead, power passes from person to person or from the task team to the task team, depending on which issue is eliminated. There is a high emphasis on individuality, risk taking and predictability of the future (Cameron \& Quinn, 2005).

\section{Innovation System Dimensions}

In addition to the dimensions that are outside the control of the organization that affects the innovation outcomes (Okatan, 2019), there are also internal innovation system dimensions for the organization that has a chance to control and it is important to understand them for innovation success. These dimensions can be controlled by companies in some way. Okatan and Alankuş (2017) compiled seven outstanding dimensions of the internal innovation systems from the literature.

\section{Innovation Leadership}

In general, the definitions of leadership reflect some basic elements such as "group", "influence" and "goal. Mostly, leadership is seen as the process of influencing others to achieve the desired results. While the influence of leaders appears to be intuitive, most behavioral leadership studies look at performance or effective results rather than innovation-related outcomes. Research on leadership form and innovative outcomes explored the theory of transformational leadership, participatory leadership and leading member exchange. As a result of research conducted with managers at different levels for companies of different sizes and ages who make radical 
innovation in the field of advanced technology, it has been determined that leadership in organizations plays a decisive role in entrepreneurship for the organization (Okatan, 2020). In recent years, more transformational and charismatic leadership approaches have gained popularity and the studies have shown a positive relationship between transformational leadership and creativity. Organizational creativity also depends on how leaders promote and manage diversity within the organization and develop an effective leadership structure that maintains the innovation process (de Jong \& Den Hartog, 2007).

\section{Innovation Motivation}

There are necessary factors for people to push their own abilities and to push for a purpose. The integration of these factors at the right time for the right purpose, mobilizes people and leads to success. The motivation phenomenon has been studied by much research. Particularly, the relationship with success indicators has been investigated in multidimensional manner. When we come about innovation and motivation, we can talk about a very close relationship. For innovation to take place, a combination of creativity and perseverance factors is required, but only through motivation. This real motivation makes innovation one of the critical and vital dimensions. Significant innovation motivation is of course highly relevant to organizational climate and culture (Hartmann, 2006).

\section{Knowledge Management}

The core of knowledge management related to innovation is that it provides a framework for management in its attempts to develop and enhance organizational capabilities for innovation. Innovation management involves the management of processes for new innovations, by combining and integrating different components of knowledge. In addition, besides explicit knowledge, implicit knowledge has a significant impact on the success of innovation processes in companies. Implicit knowledge is an important driving force in the innovation process and its effective implementation has a significant impact on the innovation process and therefore plays an important role as a company resource and success factor (Okatan, 2012). It identifies the ability of an organization to recognize, assimilate and apply the value of new external knowledge and information, and this capability is critical in determining an innovative outcome. It is argued that the expansion of this idea depends on the 
knowledge that organizations have previously absorbed the potential of producing innovation outcomes. The current knowledge base of a firm has determined the scope and ability to understand and apply new knowledge to decision making, problem solving or innovations. It is the result of the interactions between the integrative mechanisms that combine the two and the profound knowledge accumulated from expertise and the resultant discovery (Leal Rodríguez, Leal Millán, \& Roldán Salgueiro, 2013).

\section{Innovation Culture}

Researchers have examined the participation of many concepts to better understand the inputs that nourish and develop the culture of innovation. These are the theory of organization, the role of management and education management, sociology and psychology. Business, proactivity, openness to ideas, openness to action and the tendency to take risks have revealed that personality traits are the key conditions for creating a culture that promotes innovation. A strong relationship has been found between innovative initiatives and the risk-taking culture of the organization (Ismail \& Abdmajid. , 2007).

\section{Innovation Resources}

The resources are fuel and energy for an innovation. Without them, no planned innovation will come to life. In general, three main resources are mentioned: "people", "systems" and "projects". At this point, let's keep in mind that these resources are in-house resources because ultimately there are also many resources of innovation related to the environment. These three business-specific resources have strong implications for innovation success. This requires them to be managed in a very efficient and productive way. But if we need to prioritize one of them, it becomes 'people'. People have a significant impact on the functioning and success of companies. Because they create organizational culture. They lead, initiate and manage work. They are the main components of internal innovation potential (Rao \& Weintraub, 2013).

\section{Innovation Process}

Processes are the route that innovations follow as they are developed. Processes are generally based on stages or stages differentiated by some built-in actions to develop an idea for the market, where the number of steps or phases changes from one researcher / writer to another. In general, the steps include nuances that are aimed at ideas, development and launch 
to reach the market. Usually a top-level, three-step approach; it consists of developing ideas, gathering ideas and developing and implementing ideas. This process continues as a loop (Johnsson, 2016).

\section{Innovation Strategy}

A key feature of the corporate strategy should be an intentional innovation strategy aimed at accumulating company-specific information. An innovation strategy must cope with a complex and ever-changing external environment, dealing with serious uncertainties about current and future developments in technology, competitive threats and market (and nonmarket) demands. Internal structures and processes should continuously balance the potentially conflicting ones. The main requirements are:

a) identify and develop specialized knowledge in technological areas, business functions and product parts.

b) use this information through integration between technological areas, business functions and product segments (Tidd, Bessant, \& Pavitt, 2005)

While the view on organizational culture's effect on company innovativeness is well established in management literature, it has presented a somewhat high-level viewpoint regarding organizational culture - examining organizational culture just in terms of the presented innovative behaviors. Existing literature focused much on the effects of organizational culture types on innovative outputs but also there is a gap on identifying the relationship between each dimension of organizational culture and innovation system. One of the purposes of this study is to shift this focus to include the identification of the impact level of the main dimensions of the organizational culture on each dimension of the internal innovation dimensions, since the research is scarce in this area.

\section{METHODOLOGY}

We have two separate assessment tools combined in one questionnaire. So, we had the opportunity to measure organizational culture and innovation dimensions both separately and together with this approach. The first part of the questionnaire assesses the existence level of the major internal innovation dimensions combined from the literature. This questionnaire is a combined questionnaire which was also used for the assessment of the 
Understanding the Interaction of Innovation System Dimensions and Organizational Culture: A Review on Technology Firms

internal innovation capacity by Okatan \& Alankuş (2017). This part of the questionnaire consists of 51 questions assessing 7 internal innovation dimensions.

The second part of the questionnaire is the assessment of the organizational culture. We use the 'organizational culture assessment instrument' which assesses the cultural dimensions based on the logic of 'competing values framework'. This part includes 24 questions assessing 6 dimensions.

It is also important to understand the 6 dimensions of organizational culture, since these six content sizes are the basis for our assessment tool.

\section{Criteria of Success}

It is the criteria that determine how success is defined in the organization and what will be rewarded and celebrated (Cameron \& Quinn, 2005). Success criteria direct the behavior and business manner of the members of that organization.

\section{The Dominant Characteristics}

They are the dominant and most prominent features of the organization or express what the general organization looks like (Cameron \& Quinn, 2005). These dominant features are the most prominent features in the general view of an organization when viewed from the outside of the organization.

\section{Management of Employees}

It is the indicator that determines how the employees are managed or how the employees are treated and how the working environment is in terms of management (Cameron \& Quinn, 2005). Management style is one of the main factors affecting the general organizational climate and culture.

\section{Organization Glue}

It represents the organizational glue or adhesive mechanisms that hold the organization together (Cameron \& Quinn, 2005). It can also be expressed as common values that enable the organization to remain and function in integrity.

\section{Organizational Leadership}

It indicates the leadership style and approach that permeates the 
organization (Cameron \& Quinn, 2005). Leadership has a serious effect on shaping the culture in organizations and continuing in a certain style.

\section{Strategic Emphases}

It is the strategic emphasis that defines which emphasis areas drive the organization's strategy (Cameron \& Quinn, 2005). This dimension stands at an important point in determining the general direction of the organization.

Figure 2: Organizational Culture Assessment Model

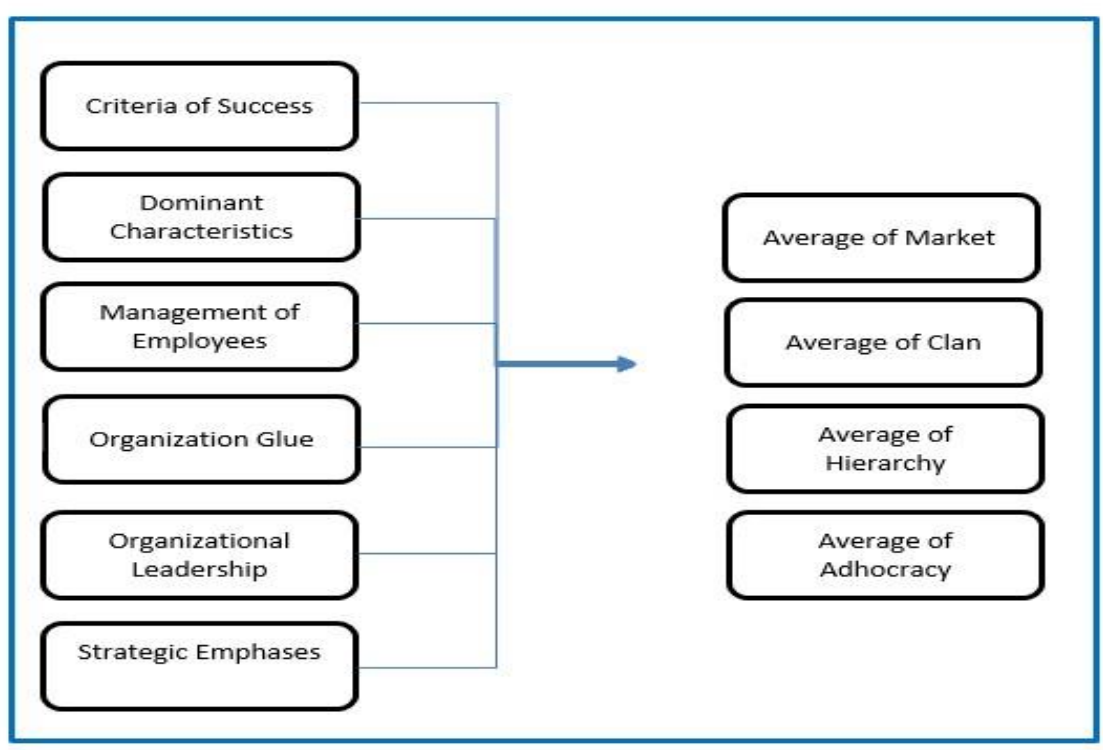

The Questionnaire includes 75 questions totally. The measuring tool uses a 5-point Likert scale. Thus, the participants had the chance to evaluate their thoughts on the questions on a 5-point scale. The evaluation of each question enabled us to measure the existence degree of all 4 cultures. The "competitive values framework" was developed by Cameron and Quinn (1999) and serves to understand whether an organization is outward or internally oriented, as well as a flexible and individual climate or a stable and controlling climate. The focus of an organization's culture is also closely related to the organization's performance (Field, 2014). At this point, this study examines the connection between innovative system performance and culture practically and focuses on revealing meaningful relationships. 
Understanding the Interaction of Innovation System Dimensions and Organizational Culture: A Review on Technology Firms

\section{Data Scope}

The data is collected form 14 corporations from miscellaneous countries. These countries are from both developed and developing countries as the USA, China, Germany, India, United Kingdom, Sweden and Turkey. Totally ' 221 ' responses were collected for the entire 14 companies. You can find the allocations of the responses per each company and the business areas of them in the table below.

Table 1: Overview of the Technology Companies

\begin{tabular}{|c|c|c|c|c|}
\hline Country & Code & Business & Employees & Participants \\
\hline TR & C 1 & $\begin{array}{l}\text { IT Application development\& system } \\
\text { integration }\end{array}$ & $\sim 1,000$ & \begin{tabular}{|l|}
17 people from \\
R\&D, Operations \\
and business \\
development \\
\end{tabular} \\
\hline USA & $\mathrm{C} 2$ & $\begin{array}{l}\text { Software development for electronic } \\
\text { payment systems }\end{array}$ & $\sim 300$ & \begin{tabular}{|l|}
10 senior \\
employees from \\
R\&D, operations \\
\end{tabular} \\
\hline USA & C 3 & $\begin{array}{l}\text { Mass Production Systems Software } \\
\text { Development }\end{array}$ & $\sim 1000$ & $\begin{array}{l}32 \text { professionals } \\
\text { from management } \\
\text { levels and R\&D }\end{array}$ \\
\hline USA & $\mathrm{C} 4$ & Industrial systems software development & $\sim 900$ & \begin{tabular}{|l|}
14 senior \\
employees and \\
executives
\end{tabular} \\
\hline TR & C 5 & $\begin{array}{l}\text { Automation systems software } \\
\text { development }\end{array}$ & $\sim 1000$ & $\begin{array}{l}17 \text { professionals } \\
\text { from management } \\
\text { levels and R\&D }\end{array}$ \\
\hline TR & C 6 & $\begin{array}{l}\text { Consumer electronics software } \\
\text { development }\end{array}$ & $\sim 800$ & $\begin{array}{l}12 \text { professionals } \\
\text { from management } \\
\text { levels and R\&D }\end{array}$ \\
\hline USA & C 7 & $\begin{array}{l}\text { Mass Production Systems Software } \\
\text { Development }\end{array}$ & $\sim 1300$ & \begin{tabular}{|l|}
26 professionals \\
from R\&D and \\
Project \\
development \\
\end{tabular} \\
\hline USA & C 8 & Software development & $\sim 400$ & $\begin{array}{l}27 \text { professionals } \\
\text { from R\&D and } \\
\text { Project } \\
\text { development }\end{array}$ \\
\hline $\mathrm{CHN}$ & C 9 & $\begin{array}{l}\text { Telecommunications software } \\
\text { development }\end{array}$ & $\sim 1700$ & $\begin{array}{l}29 \text { professionals } \\
\text { from R\&D and } \\
\text { Project } \\
\text { development } \\
\end{array}$ \\
\hline UK & C 10 & Professional Services & $\sim 220$ & \begin{tabular}{|l|}
13 senior \\
consultants \\
\end{tabular} \\
\hline TR & C 11 & Telecommunications Software & $\sim 100$ & $\begin{array}{l}24 \text { professionals } \\
\text { from R\&D and } \\
\text { Management }\end{array}$ \\
\hline SWE & C 12 & $\begin{array}{l}\text { Consumer electronics software } \\
\text { development }\end{array}$ & $\sim 500$ & $\begin{array}{l}10 \text { professionals } \\
\text { from R\&D and } \\
\text { Project } \\
\text { management } \\
\end{array}$ \\
\hline $\mathrm{DE}$ & C 13 & Computer software development & $\sim 800$ & $\begin{array}{l}24 \text { professionals } \\
\text { from R\&D and } \\
\text { Project } \\
\text { management }\end{array}$ \\
\hline IND & C 14 & IT Solution development and operations & $\sim 20$ & $\begin{array}{l}5 \text { professionals } \\
\text { from R\&D and } \\
\text { Management } \\
\end{array}$ \\
\hline
\end{tabular}




\section{Information on Company Profiles}

\section{Company 1}

The company operates in the field of software and application development in Turkey. They are listed in the 'Fast Growing Company List' of a global consulting Company and awarded as 'Best Performing Company'. The area where the company is concentrated is mostly Digitization and payment systems. The company has around 1000 employees, mostly from computer engineering area.

\section{Company 2}

The company produces technology for electronic payment transactions and value-added services at the point of sale. It was included in the list of 'best payment innovators' and offers innovative payment solutions in many countries of the world. The company is USA-based and has around 300 employees all over the world.

\section{Company 3}

The company that develops technology for large-scale production is based in the USA. It operates in many regions around the world. It is working on both software and advanced technology production systems on which this software will be based.

\section{Company 4}

It is a US-based mass production technologies and industrial production software company. The company, which operates in many countries, draws attention with its innovative works especially in the field of industry 4.0.

\section{Company 5}

It is a development and manufacturing company, developing and producing automation services, based in Turkey. It produces technology on the automotive industry production components. It has grown significantly in technology exports abroad.

\section{Company 6}

It is a consumer electronics company based in Turkey. It is the center of many patents in its name. There are large-scale research and development studies driven by the company. It is among the most innovative companies for the country and the region. 
Understanding the Interaction of Innovation System Dimensions and Organizational Culture: A Review on Technology Firms

\section{Company 7}

It is a U.S.-based company that produces technology for high-scale production platforms. It operates worldwide. It stands out with its innovative software products.

\section{Company 8}

USA-based multi-purpose, broad-based software development company. It has both software products and technology conversion consultancy. It is among the most innovative companies in the world. It operates in many countries of the world.

\section{Company 9}

It is a China-based telecommunications hardware and software and integration company. It is a company that has been shown in the most innovative companies lists and has grown very rapidly, and it does business in many countries around the world. It has more than 1000 employees

\section{Company 10}

It is a United Kingdom-based consulting company specialized in business process optimization, business transformation and implementation of the innovative structures. It serves in many countries with experienced and high-skilled professionals. It has been shown among the innovative companies of the world.

\section{Company 11}

The company operating in Turkey, has completed several R\&D projects, research and has made a significant number of patents and has contributed to the characteristics of the international standardization organizations. It works on telecommunications software and technologies. It has around 100 employees.

\section{Company 12}

It is a Sweden-based company operating in the field of consumer electronics production and related software development. The company, which has around 500 employees, has gained a reputation for offering innovative products to consumers. 


\section{Company 13}

It is a Germany-based business applications software development company that has been listed in the 'Most Innovative Companies in the World' list, which operates in many countries. It has around 800 employees worldwide.

\section{Company 14}

The company is a professional service company with more than 20 employees, based in India, focused on developing and integrating digital commerce and customer experience applications. It attracts attention with its being a fast-moving initiative with a very effective organization that supports growth.

\section{RESULTS}

While interpreting the results, it is useful to make a summary of the data studied. The implementation took place on 14 technology firms and was included in 221 valid return research models. Accordingly, we can present the outputs as follows:

- The 'market' type of culture stood out as the dominant culture in 8 of the 14 companies we studied.

- The 'clan' culture type came to the fore as the dominant culture in 5 of the 14 companies we examined.

- The number of companies in which the 'hierarchy' culture type is seen as the dominant culture is only 1 .

All 4 types of culture, which are embodied in the 'competitive values framework' we have determined for culture measurement, have been measured in all companies. According to the result of this measurement:

- The 'market' culture is seen as the most dominant type of culture, with an overall average value of 3,689 out of 5 for 14 companies surveyed.

- The 'clan' culture came to the fore as the second most dominant type of culture, with an overall average value of 3,462 out of 5 .

- The 'hierarchy' culture has been observed as the third most dominant type of culture, with an overall average value of 3,417 out of 5 . 
Understanding the Interaction of Innovation System Dimensions and Organizational Culture: A Review on Technology Firms

- The 'adhocracy' culture became the fourth most dominant type of culture, with an overall average value of 3,272 out of 5 .

Figure 3: Consolidated Average Values for all Observed Dimensions

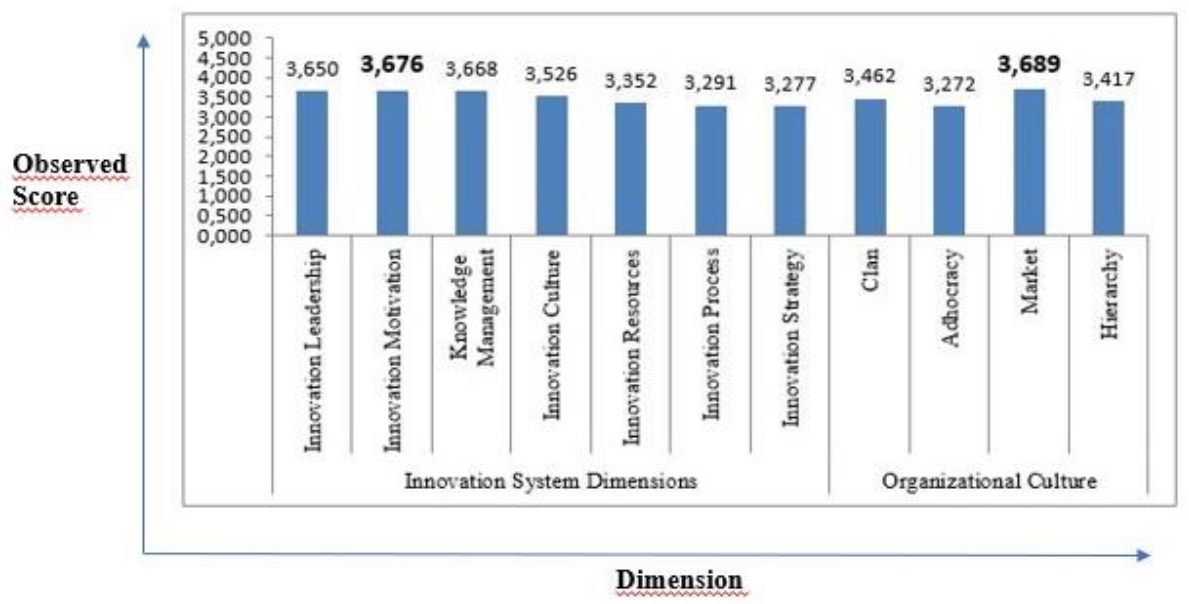

The above Figure 3 illustrates the average values for both innovation system dimensions and organizational culture based on the assessments of the sample companies. The values for each company are presented in table 2 and Table 3.

Table 2: Company Scores for Innovation System Dimensions

\begin{tabular}{|l|r|r|r|r|r|r|r|}
\hline & \multicolumn{7}{|c|}{ Innovation System Dimensions } \\
\hline Company & $\begin{array}{l}\text { Leadersh } \\
\text { ip }\end{array}$ & $\begin{array}{l}\text { Motivati } \\
\text { on }\end{array}$ & $\begin{array}{l}\text { Knowledg } \\
\text { e } \\
\text { Managem } \\
\text { ent }\end{array}$ & $\begin{array}{l}\text { Innovati } \\
\text { on } \\
\text { Culture }\end{array}$ & $\begin{array}{l}\text { Resourc } \\
\text { es }\end{array}$ & $\begin{array}{l}\text { Innovati } \\
\text { on } \\
\text { Process }\end{array}$ & $\begin{array}{l}\text { Innovati } \\
\text { on } \\
\text { Strategy }\end{array}$ \\
\hline Company 1 & 3.179 & 3.102 & 3.162 & 2.770 & 2.845 & 2.759 & 2.622 \\
\hline Company 2 & 4.000 & 3.714 & 3.526 & 3.426 & 3.400 & 3.407 & 3.429 \\
\hline Company 3 & 3.914 & 3.794 & 3.830 & 3.608 & 3.284 & 3.514 & 3.455 \\
\hline Company 4 & 3.666 & 4.143 & 4.113 & 4.453 & 4.166 & 3.814 & 3.952 \\
\hline Company 5 & 3.379 & 3.274 & 3.152 & 3.030 & 3.060 & 2.774 & 2.649 \\
\hline Company 6 & 3.250 & 3.643 & 3.640 & 3.468 & 3.394 & 3.426 & 3.643 \\
\hline Company 7 & 3.111 & 3.357 & 3.624 & 3.260 & 2.462 & 2.556 & 2.857 \\
\hline Company 8 & 3.470 & 3.314 & 3.506 & 3.350 & 3.255 & 3.537 & 3.286 \\
\hline Company 9 & 3.222 & 3.429 & 3.656 & 3.382 & 3.180 & 3.543 & 2.937 \\
\hline
\end{tabular}




\begin{tabular}{|l|l|l|l|l|l|l|l|} 
Company 10 & 4.056 & 3.619 & 3.918 & 3.040 & 2.710 & 3.518 & 3.048 \\
\hline Company 11 & 4.153 & 4.054 & 3.803 & 4.035 & 3.710 & 2.731 & 3.875 \\
\hline Company 12 & 3.650 & 3.686 & 3.761 & 3.714 & 3.791 & 3.381 & 3.186 \\
\hline Company 13 & 3.603 & 3.899 & 3.803 & 4.128 & 3.510 & 3.635 & 3.701 \\
\hline Company 14 & 4.444 & 4.429 & 3.852 & 3.695 & 4.167 & 3.481 & 3.238 \\
\hline
\end{tabular}

Table 3: Company Scores for General Organizational Culture

\begin{tabular}{|c|c|c|c|c|}
\hline \multirow[b]{2}{*}{ Company } & \multicolumn{4}{|c|}{ General Organizational Culture } \\
\hline & Clan & Adhocracy & Market & Hierarchy \\
\hline Company 1 & 3.012 & 2.631 & 3.202 & 3.000 \\
\hline Company 2 & 3.778 & 3.444 & 3.278 & 3.222 \\
\hline Company 3 & 3.685 & 3.377 & 4.142 & 3.963 \\
\hline Company 4 & 3.833 & 3.889 & 3.778 & 3.944 \\
\hline Company 5 & 3.015 & 2.636 & 3.545 & 3.303 \\
\hline Company 6 & 3.000 & 3.083 & 3.500 & 2.917 \\
\hline Company 7 & 3.222 & 2.750 & 4.056 & 3.556 \\
\hline Company 8 & 3.133 & 3.290 & 3.767 & 3.250 \\
\hline Company 9 & 2.741 & 2.889 & 3.741 & 3.222 \\
\hline Company 10 & 3.667 & 3.444 & 3.611 & 3.167 \\
\hline Company 11 & 3.875 & 3.785 & 3.847 & 3.646 \\
\hline Company 12 & 3.783 & 3.183 & 3.400 & 3.167 \\
\hline Company 13 & 3.786 & 3.571 & 3.556 & 3.532 \\
\hline Company 14 & 3.944 & 3.833 & 4.222 & 3.944 \\
\hline
\end{tabular}

'Innovation motivation' stands out as having the highest average value of 3.676 out of 5 among the 7 dimensions of the innovation system evaluated for 14 technology companies. The second highest average value was observed for "knowledge management" with 3.668 out of 5. 
Understanding the Interaction of Innovation System Dimensions and Organizational Culture: A Review on Technology Firms

Figure 4: Average Values of Culture Types According to Companies

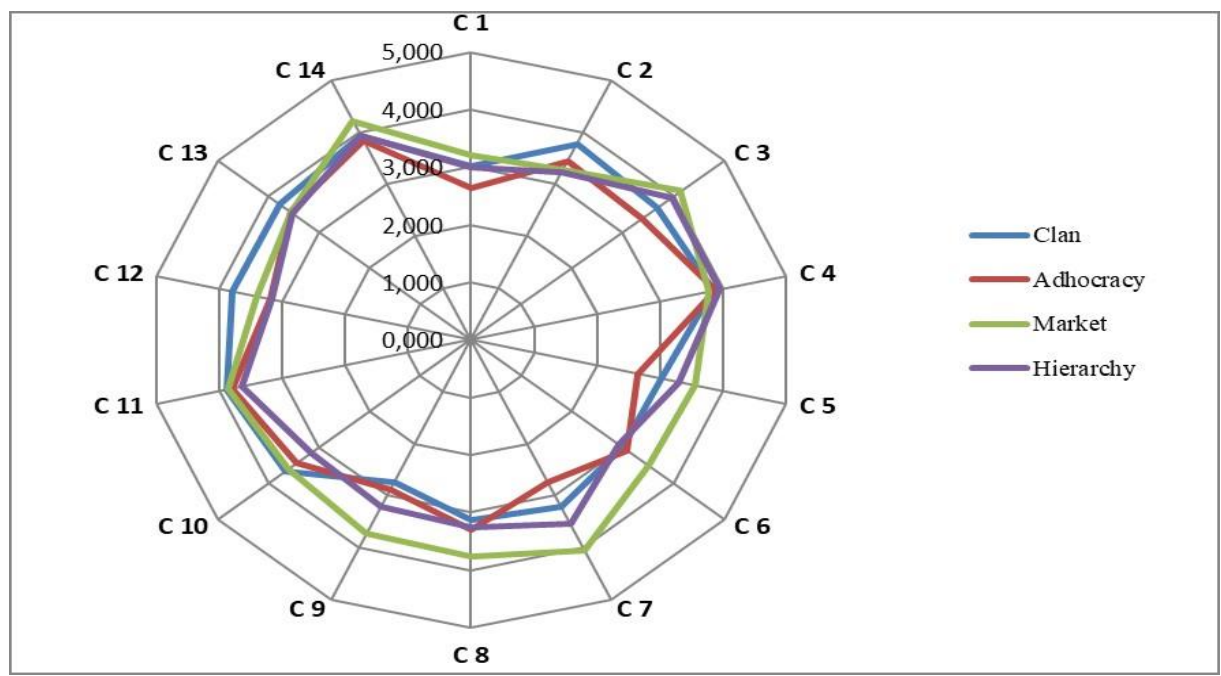

Figure 5: Average Values of Innovation System Dimensions According to Companies

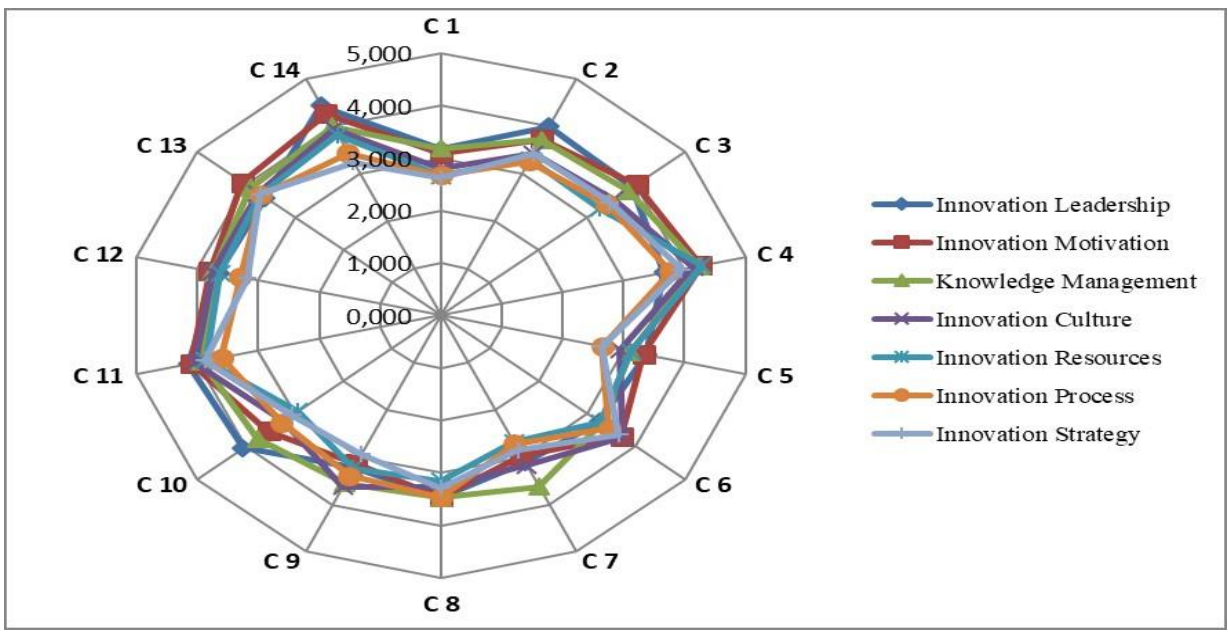

We created a research model for the regression analysis to be applied to explain the relationship between organizational culture types and the dimensions of the innovation system: 
Figure 6: Research Model

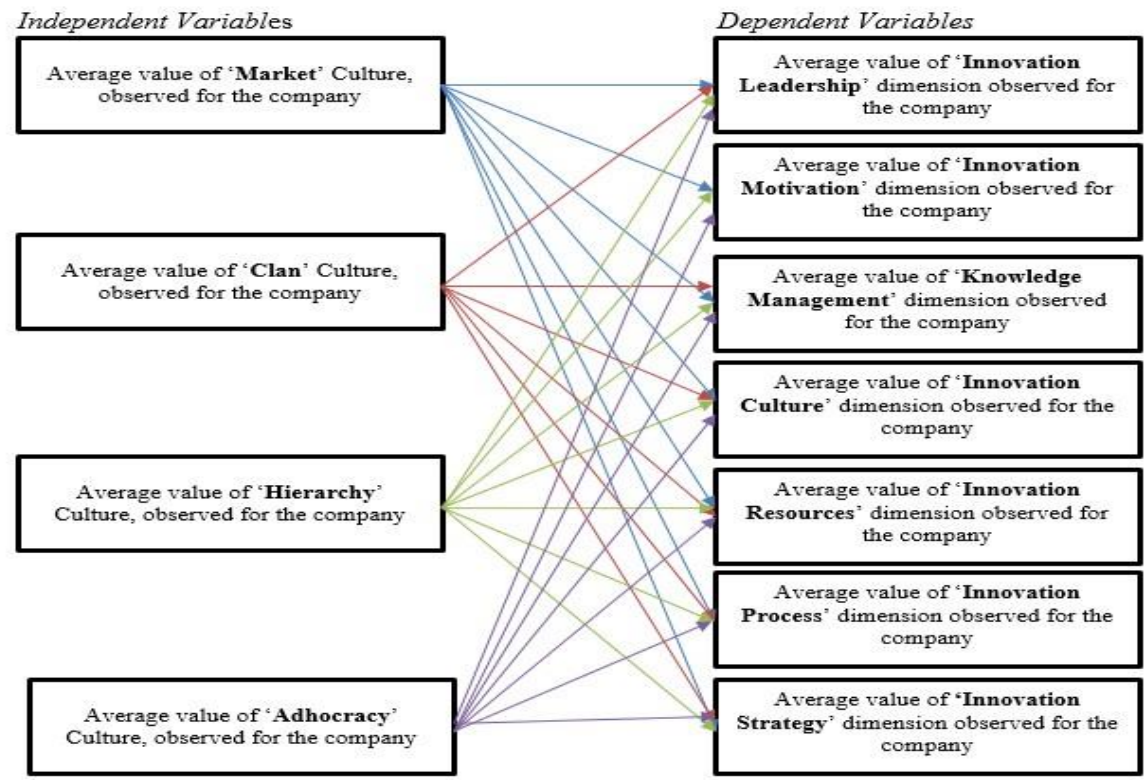

Based on the research methodology described, we analyzed the observed average values of each type of organizational culture over the observed average values of each innovation system dimension within our research scope for each organization. The important relationships prominent in the result of the multivariate regression applied in accordance with the research methodology are shown below. 
Understanding the Interaction of Innovation System Dimensions and Organizational Culture: A Review on Technology Firms

Figure 7: Significant Relations

Independent Variable Impact and Significance Dependent Variable ANOVA

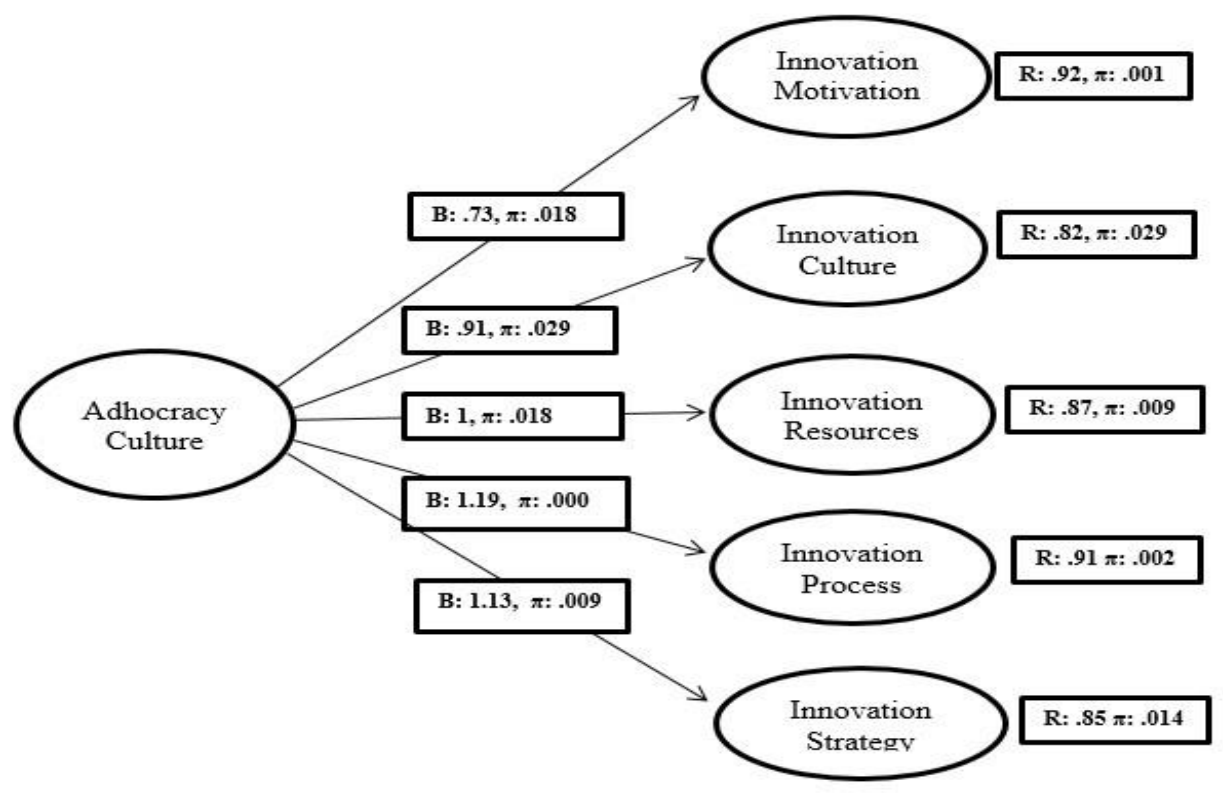

\section{CONCLUSION}

When we examined the technology companies within the scope of the study, we saw that they adopted the 'market' culture type that stands out as an externally oriented control focus that encourages target-oriented competition. The prominent feature of this kind of culture is that it adopts a structure that will maximize its competitive advantage and thus ensure profitability in order to dominate the market. Although we observed that this type of culture is the most adopted type of culture among the companies examined, we could not obtain enough outputs to prove a meaningful relationship between this type of culture and the dimensions of the innovation system. On the other hand, since our research model also measures the existence degree of 4 cultural varieties within our scope in these companies, we have also been able to prove a meaningful relationship. We observed that there was a significant and positive relationship between the 5 dimensions of the innovation system, which we examined within the scope of our study, especially with the 'adhocracy' culture type. The highlight of the 'adhocracy' culture type is that it creates 
a flexible environment that supports entrepreneurship and creativity. At the same time, we can talk about the support of the 'market' culture in some way to the 'adhocracy' culture. The 'market' culture interacts with the creativity-promoting structure of the 'adhocracy' culture, with its structure promoting competition for productivity.

When we look at the relationship of the "adhocracy" culture with dimensions of the innovation system, there is a meaningful relationship. We observe significant positive relationships with "Innovation Motivation", "Innovation Culture", "Innovation Resources", "Innovation Process" and "Innovation Strategy". The strongest significant relationship stands out with the 'innovation process' with 1.19. The lowest significant relationship is seen with 'innovation motivation' with 0.73 . When we come to the interpretation of the hypotheses, we see that the proof takes place for the following 3 hypotheses. In these hypotheses, the p-value was realized below 0.05 .

- $\mathrm{H}_{1}$ : At least one type of organizational culture is associated with the innovation dimensions of firms.

- $\mathrm{H}_{2}$ : At least one type of externally oriented organizational culture has a positive relationship with the innovation dimensions of companies.

- $\mathrm{H}_{3}$ : At least one type of organizational culture with organic processes has a positive relationship with the innovation dimensions of companies.

The motivation behind this study was to examine the relationship between the culture of organizations and the dimensions of the innovation system and to reveal meaningful relationships. Of course, culture is not the only factor affecting innovation output. For this reason, studies on the external factors and other internal factors of the organizations are also required. Choosing the organizational culture in this study is the thought that this study will be a guide for organizations that want to increase innovative competence in a shorter term, since the organization has a chance to intervene in this internal factor in a way. Leadership and general management understanding are also among the factors that the organization can intervene, and studies in this direction will also be supportive in increasing innovative competence. 
Understanding the Interaction of Innovation System Dimensions and Organizational Culture: A Review on Technology Firms

\section{REFERENCES}

[1] Cameron, K. S. (2009). An introduction to the competing values framework, Organizational culture white paper. Haworth.

[2] Cameron, K. S., \& Quinn, R. E. (2005). Diagnosing and Changing Organizational Culture: Based on the Competing Values Framework. John Wiley \& Sons.

[3] Chang, W.-J., Liao, S.-H., \& Wu, T.-T. (2017). Relationships among organizational culture, knowledge sharing, and innovation capability: a case of the automobile industry in Taiwan. Knowledge Management Research \& Practice, 15:3, 471-490 DOI: 10.1057/s41275-016-0042-6.

[4] de Jong, J., \& Den Hartog, D. (2007). How leaders influence employees' innovative behaviour. European Journal of Innovation Management, 10(1), 41-64.

doi:https://doi.org/10.1108/14601060710720546

[5] Field, M. B. (2014, 05 29).

Utilizing the_Organizational_Culture_Assessment_Instrument.

Retrieved from www.researchgate.net:

https://www.researchgate.net/publication/262033261_Utilizing_the_Orga nizational_Culture_Assessment_Instrument

[6] Hartmann, A. (2006). The role of organizational culture in motivating innovative behaviour in construction firms. Construction innovation, 6(3), 59-172.

[7] Herzog, P. (2011). Open and closed innovation: Different cultures for different strategies. . Springer Science \& Business Media.

[8] Ismail, W., \& Abdmajid, R. (2007). Framework of the culture of innovation: A revisit. Jurnal Kemanusiaan, 5(1).

[9] Johnsson, M. (2016). Innovation enablers and their importance for innovation teams. Karlskrona, Blekinge, Sweden: Doctoral dissertation, Blekinge Tekniska Högskola.

[10] Leal Rodríguez, A. L., Leal Millán, A., \& Roldán Salgueiro, J. (2013). Knowledge management and the effectiveness of innovation outcomes: 
The role of cultural barriers. The Electronic Journal of Knowledge Management, 11(1), 62-71.

[11] Okatan, K. (2012). Managing Knowledge for Innovation and Intra Networking: A Case Study. Procedia-Social and Behavioral Sciences, 62, 59-63. doi:10.1016/j.sbspro.2012.09.012

[12] Okatan, K. (2019). Effect of External Innovation Capacity on Company Level Innovativeness. Journal of Organisational Studies and Innovation, 6(4), 1-19.

[13] Okatan, K. (2020). Understanding The Management and Leadership Culture of The Innovative Automative Companies. Yönetim ve Ekonomi Araştırmaları Dergisi, 18(1), 233-248. doi:10.11611/yead.577075

[14] Okatan, K., \& Alankuş, O. B. (2017). Effect of Organizational Culture on Internal Innovation Capacity. Journal of Organisational Studies and Innovation, 18-50.

[15] Phillips, J. (2007). Creating a culture of innovation: changing your culture to accept and embrace innovation. VP Marketing.

[16] Rajapathirana, R., \& Hui, Y. (2018). Relationship between innovation capability, innovation type, and firm performance. Journal of Innovation \& Knowledge, 3(1), 44-55.

[17] Rao, J., \& Weintraub, J. R. (2013). How innovative is your company's culture? MIT Sloan Management Review, 54(3).

[18] Tian, M., Deng, P., Zhang, Y., \& Salmador, M. P. (2018). "How does culture influence innovation? A systematic literature review." Management Decision, 56(5), 1088-1107.

[19] Tidd, J., Bessant, J., \& Pavitt, K. (2005). Managing innovation integrating technological, market and organizational change. John Wiley and Sons Ltd.

[20] Wei, Y., Samiee, S., \& Lee, R. P. (2014). The influence of organic organizational cultures, market responsiveness, and product strategy on 
Understanding the Interaction of Innovation System Dimensions and Organizational Culture: A Review on Technology Firms

firm performance in an emerging market. Journal of the Academy of Marketing Science, 42(1), 49-70.

[21] Yesil, S., \& Kaya, A. (2013). The Effect of Organizational Culture on Firm Financial Performance: Evidence from a Developing Country (Vol. 81). Procedia - Social and Behavioral Sciences.

[22] Zhang, X., Chen, H., Wang, W., \& Ordóñez de Pablos, P. (2016). What is the role of IT in innovation? A bibliometric analysis of research development in IT innovation. Behaviour \& Information Technology, 1130-1143. doi:10.1080/0144929X.2016.1212403 